\title{
In vivo patch-clamp analysis of dopaminergic antinociceptive actions on dorsal horn neurons in the spinal cord
}

\author{
Wataru Taniguchi ${ }^{1}$, Terumasa Nakatsuka ${ }^{2}$, Nobuyuki Miyazaki ${ }^{1}$ \\ Noboru Takiguchi ${ }^{1}$, Yae Sugimura ${ }^{1}$, and Munehito Yoshida ${ }^{1}$ \\ ${ }^{1}$ Department of Orthopaedic Surgery, Wakayama Medical University \\ ${ }^{2}$ Pain Research Center, Kansai University of Health Sciences
}

\begin{abstract}
Dopamine (DA) is well known as a neurotransmitter and neuromodulator in the brain, not only as a precursor in the synthesis of other catecholamines. DA controls a variety of functions including locomotor activity, cognition, emotion, positive reinforcement, food intake, and endocrine regulation. Compared with the enormous literature devoted to DA actions in the brain, little is known about the roles of DA in the spinal cord. To elucidate the mechanisms of antinociception mediated by the dopaminergic descending pathway in the spinal cord, we investigated the actions of DA on substantia gelatinosa (SG) neurons by in vivo whole-cell patch-clamp methods. In the voltage-clamp mode $\left(V_{\mathrm{H}}=-70 \mathrm{mV}\right)$, the application of DA induced outward currents in about $70 \%$ of SG neurons tested. DA also significantly suppressed the frequency and amplitude of glutamatergic spontaneous excitatory postsynaptic currents (EPSCs). DA-induced outward current was observed in the presence of TTX or a non-NMDA receptor antagonist, CNQX. DA also significantly decreased the frequency of miniature EPSCs in the presence of TTX. These results suggest that DA has both presynaptic and postsynaptic inhibitory actions on synaptic transmission in SG neurons. The DA-induced outward current was completely blocked by either GDP- $\beta-S$ in the pipette solution or by perfusion of a non-selective $\mathrm{K}^{+}$channel blocker, $\mathrm{Ba}^{2+}$. Moreover, the DAinduced outward currents were mimicked by a selective D2-like receptor agonist, quinpirole, but not by a D1-like receptor agonist, SKF 38393. In addition, the DA-induced outward current was attenuated by a selective D2-like receptor antagonist, sulpiride. These findings suggest that the DAinduced outward current is mediated by $\mathrm{G}$-protein-activated $\mathrm{K}^{+}$channels through D2-like receptors. Furthermore, we investigated whether DA has direct antinociceptive actions into noxious and innocuous stimuli on the receptive field skin of recording SG neuron. The results showed that DA produced direct analgesic effects in SG neurons to both noxious and innocuous
\end{abstract}


stimuli to the skin. These findings suggest the dopaminergic descending pathway has an antinociceptive effect via D2-like receptors on SG neurons in the spinal cord.

Keywords

Dopamine; in vivo patch-clamp; D2-like receptor; Pain; Analgesia

Received: 2 March 2011

Accepted: 8 April 2011

\section{in vivo patch-clamp 法を用いた脊䯣後角におけるドパミン疼痛抑制作用機序の解析}

谷口 亘 $1 /$ 中塚 映政 $2 /$ 宮崎 展行 $1 /$ 瀧口 登 $1 /$ 杉村 弥恵 $1 /$ 吉田 宗人 1

1 和歌山県立医科大学 整形外科学教室

2 関西医療大学 保健医療学部 疼痛医学分野

\section{はじめに}

内因性鎮痛機構の一つに下行性疼痛抑制系が あり, ノルアドレナリン作動神経系, セロトニ ン作動神経系がその役割を担っていることはよ く知られている。しかしながら，ノルアドレナ リンの前駆物質であるドパミンが知覚に関して どのような作用を及ぼすか未だ明らかではな い。ドパミンは脳内に広範囲に分布する主要な 神経伝達物質である 1)。ドパミン受容体は 7 回 膜貫通型のペプチド構造を有し，G蛋白と共役 している。サブタイプには D1 から D5 が存在 し， D1, D5 の D1-like 受容体，D2, D3, D4の D2-like 受容体に大別できる 1,2)。ドパミンは 脳レベルにおいて運動, 認知, 感情, 動機強 化, 食欲, 内分泌調整など多彩な生理活性作用 を有する。また，近年，脳レベルにおいてドパ ミンが疼痛に関連することを示唆する研究報告 が散見されるようになり3)，各領域でドパミン
が直接の疼痛抑制作用を有することが指摘され ている。しかしながら，泰髄レベルでのドパミ ン作動性神経系の役割については依然不明な点 が多い。ドパミン作動性神経系として, 黒質線 条体路, 中脳辺縁路, 視床下部下垂体路, そし て視床下部脊髄路の 4 経路が知られている。視 床下部脊髄路は視床下部の後部 A11 から脊髄 に投射されていることが比較的古くから知られ ていたが 4,5), 他の経路と違ってその機能は不 明である。過去に視床下部 A11 電気刺激で鎮 痛効果が得られることや 6,7), ドパミンあるい はドパミン作動薬の髄腔内投与での鎮痛効果が 行動学的に報告されていることから ${ }^{8,9,10)}$, ド パミン作動神経系には既知のセロトニン作動神 経系やノルアドレナリン作動神経系と同様に下 行性疼痛抑制系としての機能を有する可能性が ある。今回, 我々はin vivo パッチクランプ法 を用いて脊䯣後角感覚ニューロンでのドパミン の作用を解析したので報告する。 


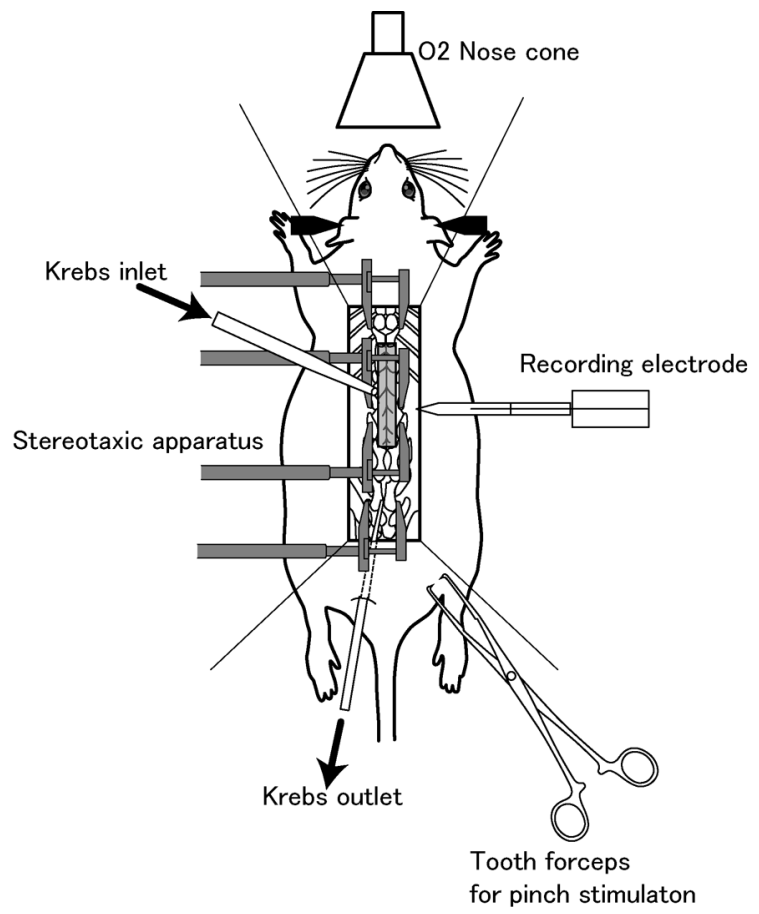

Fig.1 Schematic diagrams of in vivo rat preparation.

Whole-cell patch-clamp recordings were done while supplying oxygen to a urethane-anesthetized rat through a nose cone. Drugs were dissolved in Krebs solution and applied by perfusion. The noxious and innocuous mechanical stimuli were applied to the receptive field of the ipsilateral hindlimb with toothed forceps and air puffs.

\section{方法}

本害験の計画は和歌山県立医科大学動物実験 委員会の審査を受けて承認された。

\section{（1）ラット脊髄 in vivo 標本の作製}

ラット脊髄 in vivo 標本の作製は Sonohata らの方法 11)に従った。5〜8 週齢の成熟 Sprague-Dawley 系雄性ラットを使用した。 ラットをウレタン（腹腔内投与 : $1.2 \sim 1.5 \mathrm{~g} / \mathrm{kg}$ ) で麻醉後, 呼吸管理はマスクによる酸素投与を
行った。胸腰椎部で背側に皮切を行い, 傍脊柱 筋群を切離した。脊椎を露出し, Th13 から L2 まで椎弓切除を行った。この状態でラットを脊 髄固定器に移す。まず，イヤーバーおよび中胸 椎部と下位腰椎で 3 点固定し, 皮切部の辺縁を 錘で 4 方向に引き上げることでプールを作成 し, 脊髄表面を約 $36^{\circ} \mathrm{C}$ の酸素負荷した人工脳 脊髄液 $\left(\mathrm{NaCl} 117 \mathrm{mM}, \mathrm{KCl} 3.6 \mathrm{mM}, \mathrm{CaCl}_{2}\right.$ $2.5 \mathrm{mM}, \mathrm{MgCl}_{2} 1.2 \mathrm{mM}, \mathrm{NaH}_{2} \mathrm{PO}_{4} 1.2 \mathrm{mM}$, glucose $11 \mathrm{mM}$, and $\mathrm{NaHCO} 325 \mathrm{mM}$ ) で灌流 した (Fig.1)。実体顕微鏡下に硬膜を縦切開・切 除し, 後根を露出し, 腰傍大部レベルで後根を 内外側に分け，電極刺入スペースを作成した。 この時点で電極刺入部近くの頭側と尾側の脊椎 固定を追加し, 合計 5 点固定とする。呼吸によ る脊鹃道の振動が抑制できていることを確認した 上で, クモ膜と軟膜に電極刺入用の開空を行 い, 記録の準備を行った。

\section{（2）神経細胞からのパッチクランプ法}

マイクロマニュピレターで電極を脊髄内に刺 入し, $5 \mathrm{mV}$ ステップに対する応答電流の変化 を指標にギガシールを形成するいわゆるブライ ンドパッチクランプ法によって記録を行う。記 録用電極には potassium gluconate $135 \mathrm{mM}$, $\mathrm{KCl} 5 \mathrm{mM}, \mathrm{CaCl}_{2} 0.5 \mathrm{mM}, \mathrm{MgCl}_{2} 2 \mathrm{mM}$, EGTA $5 \mathrm{mM}$, ATP-Mg $5 \mathrm{mM}$, and Hepes$\mathrm{KOH} 5 \mathrm{mM}$ を充填した先端電極抵抗 8〜 $12 \mathrm{M} \Omega$ の微小電極を用いた。薬液の灌流は人 工脳脊髄液と同ラインを用いて行う。ドパミン およびその関連物質を灌流投与し, それらが金 㖪後角感覚ニューロンの興奮性シナプス伝達に 及ぼす作用を検討する。また，記録ニューロン の皮膚受容野を同定した上で同部位に疼痛刺激 と触刺激を加え, コントロール時とドパミン存 在下において興奮性シナプス後電流 (excitatory 
postsynaptic currents；EPSC）および興奮性シ ナプス後電位 (excitatory postsynaptic potentials; EPSP), 活動電位 (action potential; AP) の大きさを比較した。疼痛刺激には有鈎鉗子, 触刺激には定圧の空気を噴霧することにより, 末梢刺激を定量的に行った。得られた記録電 流・電位はパッチクランプ用アンプ(Molecular Devices 社 Axopatch200B), A/D 変換器 (Molecular Devices 社 Digidata 1440A)，デー 夕記録・解析用ソフト (Molecular Devices 社 pClamp10, Synaptosoft 社 Mini Analysis 6.0) を用いて記録および解析を行った。デー夕は mean \pm S.E.M.で表示した。検定には paired t-test， t-test を用いた。危険率 $5 \%(p<0.05)$ を もって有意と判断した。

\section{結 果}

電圧固定法により記録膜電位を $-70 \mathrm{mV}$ に固 定した。ドパミン $(100 \mu \mathrm{M})$ を 2 分間潅流させ ると細胞膜の過分極を示す外向き電流の発生を 認めた（Fig.2-A）。外向き電流は記録した 219 細胞中 155 細胞 $(70.8 \%)$ で認め，平均振幅は $19.5 \pm 1.6 \mathrm{pA}(n=64)$ であった。また，記録した ニューロン中で EPSC の頻度, 振幅を解析し たところ, spontaneous EPSC の頻度・振幅が 有意に減少していた（Fig.2-B）。次に，ドパミ ンの作用が脱感作するかどうかを調べた。ドパ ミンの反復投与や長時間投与にても外向き電流 の減弱はなく，脱感作はみられなかった。

ナトリウムチャネル阻害薬であるテトロドト キシン (TTX, $1 \mu \mathrm{M})$ 存在下では微小興奮性シ ナプス後電流 (miniature EPSC; mEPSC) が観 察できる。TTX 存在下にドパミンを投与した

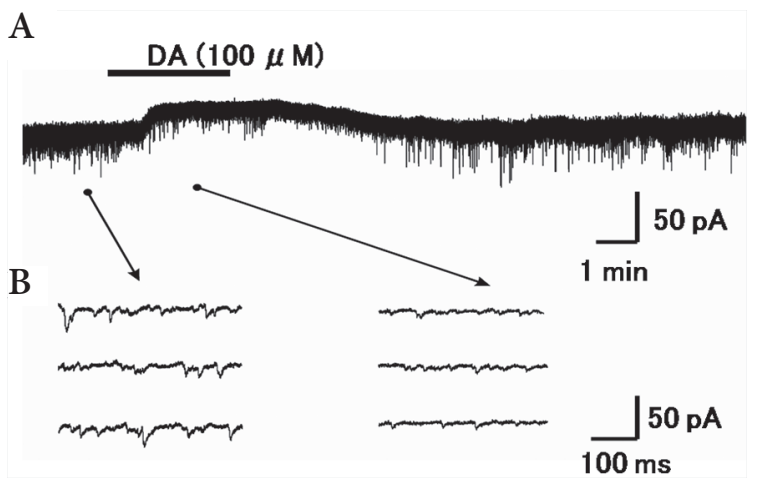

Fig.2

A: In voltage-clamp mode $\left(V_{H}=-70 \mathrm{mV}\right)$, bath application of DA $(100 \mu \mathrm{M})$ produced an outward current. B: The three traces, shown in an expanded scale in time, indicate that the frequency and amplitude of EPSCs are clearly reduced during DA perfusion compared with those of controls.

A

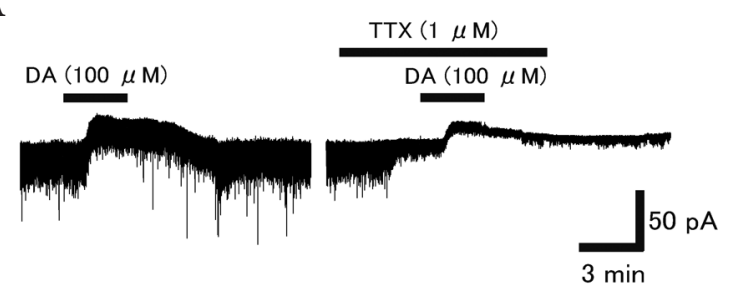

B

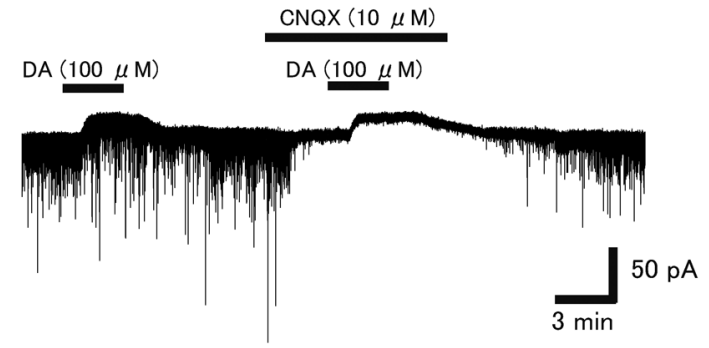

Fig.3

A: During the simultaneous application of TTX $(1 \mu \mathrm{M}), \mathrm{DA}$ also induced outward currents. B: In the presence of CNQX $(10 \mu \mathrm{M})$, DA induced an outward current without any decrease in the amplitude.

ところ, mEPSC は振幅に有意差はでなかった

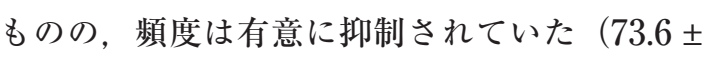
$9.4 \%$ of the controls; $n=10, p<0.05)$ 。本結果か ら, ドパミンは脊䯣後角感覚ニューロンの膜を 
A

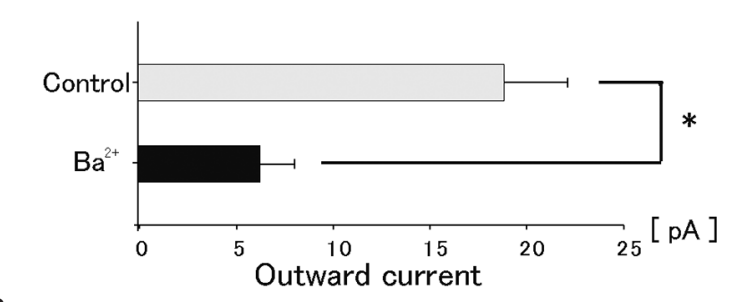

B

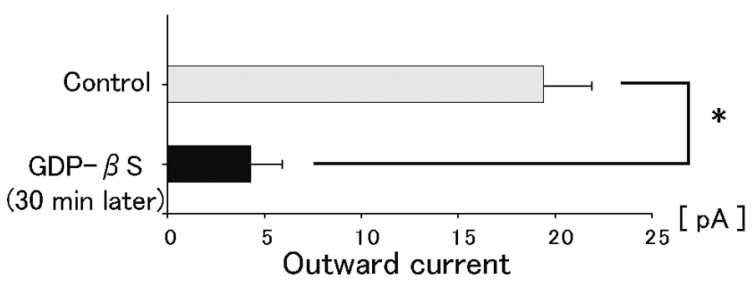

Fig.4

A: The outward current was significantly reduced in the presence of $\mathrm{Ba}^{2+}(34.7 \pm 7.8 \%$ of the controls; $n=8$; $p<0.05)$. B: An outward current was recorded with potassium gluconate pipette solution containing GDP- $\beta-S$. DA produced an outward current just after establishing whole-cell recording, but it was markedly attenuated when DA was again applied 30 min later $(22.3 \pm 8.9 \%$ of control amplitude; $n=8 ; p<$ 0.01).

過分極するとともに一次求心性線維から興奮性 神経伝達物質であるグルタミン酸の遊離を抑制 することが判明した。また, TTX 存在下でも 外向き電流は減弱しなかった（ $n=10 ） （$ Fig.3A)。次に, グルタミン酸受容体拮抗薬の 6 cyano-7-nitroquinoxaline-2,3-dione (CNQX, $10 \mu \mathrm{M})$ 存在下でドパミン投与を行うと EPSC は完全に消失したが, 外向き電流は減弱しな かった $(n=5)($ Fig.3-B)。

さらに,ドパミンによって惹起される外向き 電流に関与するイオンチャネルを調べるため, 非選択的カリウムチャネル拮抗薬であるバリウ ム $(1 \mathrm{mM})$ 存在下でドパミンの作用を観察し た。バリウム非存在下と比較してバリウム存在 下では有意に外向き電流は減少した $(34.7 \pm$ $7.8 \%$ of the controls; $n=8, p<0.05) （$ Fig. $4-\mathrm{A}$ )。
A

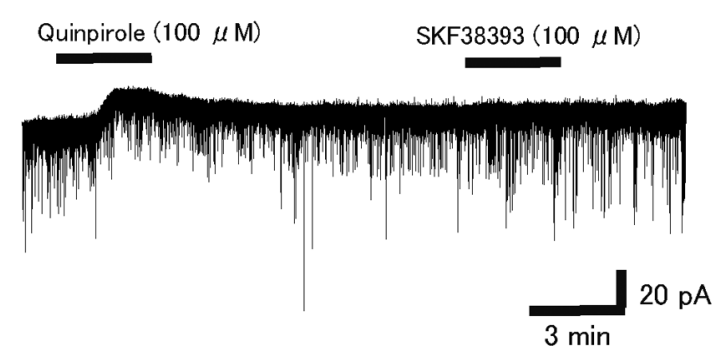

B

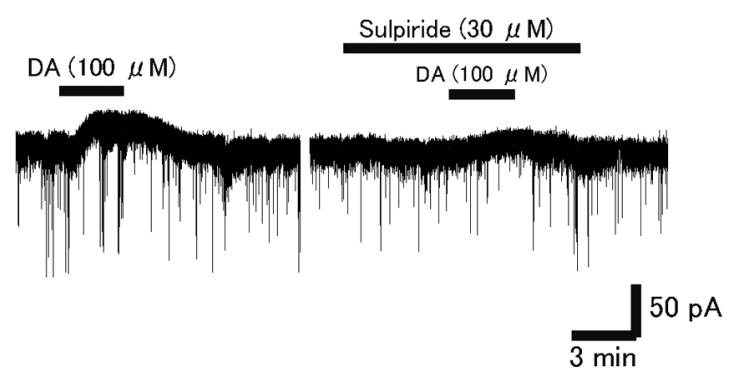

Fig. 5

A: Quinpirole $(100 \mu \mathrm{M})$, a D2-like receptor agonist, mimicked the DA-induced outward current. SKF $38393(100 \mu \mathrm{M})$, a D1-like receptor agonist, induced no outward current, whereas quinpirol induced an outward current in the same neuron. B: In the presence of a D2-like receptor antagonist, sulpiride (30 $\mu \mathrm{M})$, a DA-induced outward current was markedly attenuated.

また，細胞膜 Gタンパク質の活性を阻害する GDP- $\beta S$ を電極内に混入して記録すると, 記 録当初はドパミンによる外向き電流が発生した が, 30 分以上小いて再度ドパミン投与すると, その振幅は有意に減少した $(22.3 \pm 8.9 \%$ of the controls; $n=8, p<0.01)$ (Fig.4-B)。以上の結果 から, ドパミン受容体の活性化によって, 細胞 膜 $\mathrm{G}$ 蛋白質の活性化を介してカリウムチャネル を開口し，抑制性電流が発生することが判明し た。

ドパミンによって惹起される外向き電流がど のようなサブタイプの受容体によるものかを検 討した。D1-like 受容体作動薬である SKF 38393 $(100 \mu \mathrm{M})$ 投与を行ってもほとんど外向き電流 


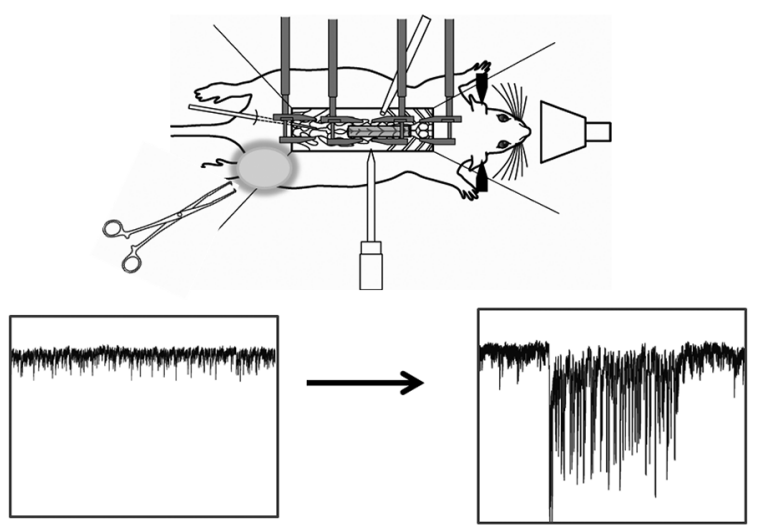

Fig.6 A response to innocuous (air puff) or noxious (pinch) mechanical stimuli.

The pinch stimulus produced a large barrage of EPSCs.

は発生しなかったが $(1.9 \pm 0.6 \mathrm{pA} ; n=9), \mathrm{D} 2-$ like 受容体作動薬である quinpirole $(100 \mu \mathrm{M})$ を投与すると, ドパミン投与時と同様の外向き 電流が観察できた $(15.7 \pm 2.0 \mathrm{pA} ; n=9)$ (Fig.5A)。また, D2-like 受容体拮抗薬の Sulpiride $(30 \mu \mathrm{M})$ 存在下ではドパミンによって惹起され る外向き電流は有意に阻害された $(34.1 \pm 10.0 \%$ of the controls; $n=6, p<0.05)$ (Fig.5-B)。以上 の結果から, 脊䯣後角感覚ニューロンには D2-like 受容体が発現していることが判明し た。

ラットの下肢に刺激を加えると EPSC が激 しく連続して発火するが（Fig.6），その反応を ドパミン存在下と非存在下で比較し, 未梢皮虞 刺激に対するドパミンの作用を検討した。触刺 激は圧刺激装置を使用し，一定の圧で 5 秒間空 気を吹き付けることで定量化した。空気を吹き 付けると脊髄後角ニューロンに打いて EPSC の増加が記録された。ドパミン投与下では非存 在下と比較して触刺激による EPSC の発生頻 度，基線と EPSC 波形の形成する面積は有意 に減少した(発生頻度 [ $70.9 \pm 11.0 \%$ of control；
A

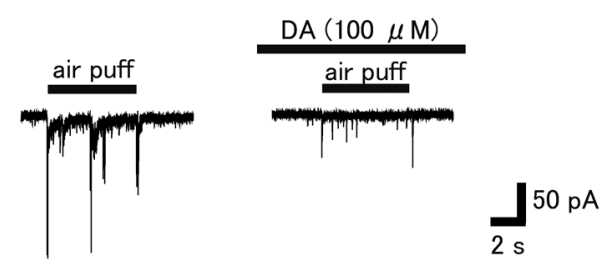

B

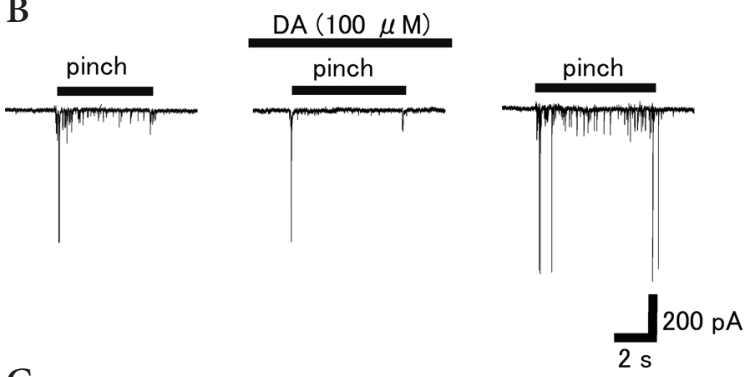

C
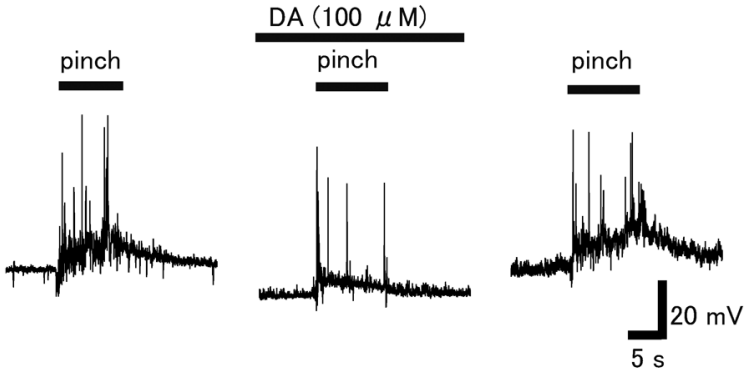

Fig.7

A: EPSCs elicited by air puff in voltage-clamp mode $(V \mathrm{H}=-70 \mathrm{mV})$ in control. DA suppressed repeated EPSCs during air puff. B: EPSCs elicited by pinching in voltage-clamp mode $\left(\mathrm{VH}_{\mathrm{H}}=-70 \mathrm{mV}\right)$ in control. DA $(100 \mu \mathrm{M})$ suppressed repeated EPSCs during pinching in a reversible manner. C: Pinch stimuli produced a barrage of EPSPs accompanied by action potentials under a current-clamp condition. DA hyperpolarized SG neuron and inhibited the action potentials in a reversible manner.

$n=18, p<0.01]$, 面積 $[80.6 \pm 6.3 \%$ of control; $n=18, p<0.01$ ]) (Fig.7-A)。また, 疼痛刺激を 定量的に行うために有鈎鉗子で 5 から 10 秒間 挟んだ。触刺激と同様にドパミン存在下では非 存在下と比較して疼痛刺激によるEPSC の発 生頻度, 面積は有意に減少した（発生頻度 [74.6 $\pm 7.5 \%$ of control; $n=6, p<0.05]$, 面積 [78.0 $\pm 8.0 \%$ of control; $n=6, p<0.05]$ ) (Fig.7- 
B)。また，電流固定法で AP，EPSP の発生を 観察すると, ドパミン存在下では非存在下と比 較してAP, EPSP は発生頻度ならびに面積が 有意に減少した（発生頻度 $[70.2 \pm 12.4 \%$ of control; $n=9, p<0.05$ ], 面積 [ $42.7 \pm 6.9 \%$ of control; $n=9, p<0.01]$ ) (Fig.7-C)。

\section{考察}

既知の下行性疼痛抑制系として橋レベルの青 斑核由来のノルアドレナリン作動性神経系，延 䯣レベルの大縫線核由来のセロトニン作動性神 経系が確立されているが 12,13,14)，同じアミン類 のドパミン作動神経系に下行性疼痛抑制系の働 きがあるかどうかは不明であった。過去に視床 下部 A11 電気刺激で鎮痛効果が得られること や，ドパミンあるいはドパミン作動薬の髄腔内 投与での鎮痛効果が行動学的に報告されている ことから同じアミン類のドパミンにも下行性疼 痛抑制性の作用があると我々は仮説を立て，本 研究を行ってきた。我々は脊髄スライスパッチ 標本にクランプ法を適用した研究により，脊髄 後角の感覚ニューロンにはD2-like 受容体が 発現し, 細胞膜を過分極させる作用が存在する ことを報告した 10)。今回，in vivoパッチクラ ンプ法にても同様にドパミンは脊髄感覚ニュー ロンの膜を過分極させる作用を確認した。ま た，この作用は脊䯣後角感覚ニューロンには D2-like 受容体が発現していて，ドパミンに よって活性化されると細胞膜 $\mathrm{G}$ タンパク質の活 性化を介してカリウムチャネルが開口すること で細胞膜が過分極することが判明した。この作 用はシナプス後性作用であるが，TTX存在下 で miniature EPSC の頻度も抑制されたことか
ら，ドパミンはシナプス前性にも作用すること が判明した。すなわち, ドパミン受容体は一次 求心性線維終末部にも発現しており, その活性 化によってグルタミン酸の放出を抑制すること が明らかになった。またこれらのドパミンの 作用は皮膚侵害・非侵害刺激に対しても脊髄し ベルにおいてドパミンが直接抑制する作用を有 することが本研究において証明された。

ドパミンの経路としては黒質線条体路, 中脳 辺縁路, 視床下部下垂体路, 視床下部脊髄路の 4 経路が存在する。視床下部脊髄路は A11 か ら脊髄に投射されていることが比較的古くから 知られていた。脊髄内にはドパミンを含有する 神経線維や終末は存在するが細胞体は存在しな いこと ${ }^{15)}$, 後根神経節においては少量存在す るがその濃度は脊髄の $1 / 10$ であること ${ }^{16)}$ ，ま た神経根を刺激して脊䯣後角で記録した際に今 回ドパミンによって発生した外向き電流が観察 されないことから 17$)$ ，春髄レベルで作用する ドパミンの供給は視床下部春髄路からの投射に よると考えるのが妥当である。この点を考慮す ると, 今回の我々の研究結果から, 未梢皮膚刺 激が後根神経節を経由して後角感覚ニューロン に伝わるが，その刺激は視床下部 A11 ニュー ロンから投射されるドパミンによってシナプス 前性・後性に制御を受けている，つまり，ドパ ミン作動性神経系は下行性疼痛抑制系として機 能していることが示唆された。

\section{結語}

脊髄後角レベルにおけるドパミン作動性神経 系をin vivo パッチクランプ法を用いて解析し た。脊髄後角感覚ニューロンにはD2-like 受 
容体が発現しており，その活性化により細胞膜

$\mathrm{G}$ タンパク質を介してカリウムチャネルが開口

し，感覚ニューロンの膜が過分極することが明

らかとなった。さらに, 皮膚侵害受容に対し

て，ドパミンは春髄レベルで抑制作用を有する

ことが明らかとなった。

本研究からドパミン作動性神経系である視床

下部脊鹃道路には下行性疼痛抑制系としての作用

を持つことが示唆された。

\section{文 献}

1) Missale, C., Nash, S.R., Robinson, S.W., Jaber, M., Caron, M.G., Dopamine receptors: from structure to function, Physiol. Rev., 78(1998) 189-225.

2) Vallone, D., Picetti, R., Borrelli, E., Structure and function of dopamine receptors, Neurosci. Biobehav. Rev., 24(2000) 125-132.

3) Potvin, S., Grignon, S., Marchand, S., Human evidence of a supra-spinal modulating role of dopamine on pain perception, Synapse, 63 (2009)390-402.

4) Björklund, A., Skagerberg, G., Evidence for a major spinal cord projection from the diencephalic A11 dopamine cell group in the rat using transmitter-specific fluorescent retrograde tracing, Brain. Res., 177 (1979) 170-175.

5) Skagerberg, G., Bjorklund, A., Lindvall, O., Schmidt, R.H., Origin and termination of the diencephalo-spinal dopamine system in the rat, Brain. Res. Bull., 9 (1982) 237-244.

6) Fleetwood-Walker, S.M., Hope, P.J., Mitchell, R., Antinociceptive actions of descending dopaminergic tracts on cat and rat dorsal horn somatosensory neurons, J. Physiol., 399 (1988) 335-348.

7) Wei, H., Viisanen, H., Pertovaara, A., Descending modulation of neuropathic hypersensitivity by dopamine D2 receptors in or adjacent to the hypothalamic A11 cell group, Pharmacol. Res., 59(2009) 355-363.

8) Barasi, S., Duggal, K.N., The effect of local and systemic application of dopaminergic agents on tail flick latency in the rat, Eur. J. Pharmacol., 117 (1985) 287-294.
9) Liu, Q.S., Qiao, J.T., Dafny, N., D2 dopamine receptor involvement in spinal dopamine-produced antinociception, Life. Sci., 51 (1992) 1485-1492.

10) Tamae, A., Nakatsuka T., Koga, K., Kato, G., Furue, H., Katafuchi, T., Yoshimura, M., Direct inhibition of substantia gelatinosa neurons in the rat spinal cord by activation of dopamine D2-like receptors, J. Physiol., 568(2005) 243253.

11) Sonohata, M., Furue, H., Katafuchi, T., Yasaka, T., Doi, A., Kumamoto, E., Yoshimura, M., Actions of noradrenaline on substantia geltatinosa neurones in the rat spinal cord revealed by in vivopatchrecording, J. Physiol., 555 (2) (2003) 515-526.

12) Millan, M.J., Descending control of pain, Prog. Neurobiol., 66 (2002)355-474.

13) Sandkühler, J., The organization and function of endogenous antinociceptive systems, Prog. Neurobiol., 50 (1996) 49-81.

14) Yoshimura, M., Furue, H., Mechanisms for the anti-nociceptive actions of the descending noradrenergic and serotonergic systems in the spinal cord, J. Pharmacol. Sci., 101 (2006) 107117.

15) Holstege, J.C., Van Dijken, H., Buijs, R.M., Goedknegt, H., Gosens, T., Bongers, C.M., Distribution of dopamine immunoreactivity in the rat, cat and monkey spinal cord, J. Comp. Neurol., 376 (1996)631-652.

16) Weil-Fugazza, J., Onteniente, B., Audet, G., Philippe, E., Dopamine as trace amine in the dorsal root ganglia, Neurochem. Res., 18(1993) 965-969.

17) Nakatsuka, T., Ataka, T., Kumamoto, E., Tamaki, T., Yoshimura, M., Alteration in synaptic inputs through $\mathrm{C}$-afferent fibers to substantia gelatinosa neurons of the rat spinal dorsal horn during postnatal development, Neuroscience, 99 (2000)549-556.

Address for correspondence: Wataru Taniguchi Department of Orthopaedic Surgery,

Wakayama Medical University

811-1 Kimiidera, Wakayama City,

Wakayama 641-8509, Japan 